\title{
Growth Suppression of Chenopodium album Weed and Growth Promotion Effect on Wheat (Triticum aestivum L.) by Inoculation of $\delta$-Aminolevulinic Acid Producing Rhizobacteria
}

\author{
Aakanksha Khandelwal, Anju Sehrawat and Satyavir S. Sindhu* \\ Department of Microbiology, CCS Haryana Agricultural University, Hisar-125 004, India \\ *Corresponding author
}

Keywords

Chenopodium album, Wheat, Rhizobacterial isolates, ALA production, IAA production, ACC utilization, Growth retardation

Article Info

Accepted:

17 January 2018

Available Online:

10 February 2018

\section{A B S T R A C T}

Weeds are the most underestimated crop pests in agriculture and cause $37-40 \%$ reduction in the yields of various crops. They decrease quantity and quality of farm produce/food, forage/fodder and animal products (meat and milk), and cause health hazards for humans and animals. Thus, weed control is indispensable in every crop production system. The present study was undertaken to evaluate the herbicidal activity of rhizosphere bacteria against the Chenopodium album (bathu) weed. Ninety five bacteria were obtained from the rhizosphere of wheat and mustard, and screened for ALA ( $\delta$-aminolevulinic acid) production. Overall, $80 \%$ of the rhizobacterial isolates produced ALA. Out of these, 10 bacterial isolates were selected for retardation or stimulation effect on seed germination of Chenopodium album weed on $0.8 \%$ agar incorporated plates. Four rhizobacterial isolates showed root growth inhibition and three bacterial isolates caused shoot growth inhibition at both $5^{\text {th }}$ and $10^{\text {th }}$ day of seed germination. Four rhizobacterial isolates showed moderate growth on ACC supplemented plates. Similarly, production of IAA varied in different rhizobacterial isolates and five isolates produced more than $4.0 \mu \mathrm{g} \mathrm{ml}^{-1}$ IAA. Based on beneficial attributes, three bacterial isolates WHA82, MSA39 and WHA100 were examined for their effect on growth of wheat and weed under pot house conditions. Inoculation of bacterial isolate MSA39 caused 43-53\% decrease in root dry weight (RDW) and 31-47\% decrease in shoot dry weight (SDW) of Chenopodium album at 60 and 90 days of plant growth, whereas its inoculation showed $122-144 \%$ increase in RDW and 205-124\% increase in SDW of wheat. Inoculation with bacterial isolates WHA82 and WHA100 also decreased root and shoot dry weight of $C$. album at both the stages of observations. These rhizospheric bacterial isolates MSA39 and WHA100 could be further tested for suppression of weed growth under field conditions for their subsequent application as biofertilizer and bioherbicide.

\section{Introduction}

Biotic and abiotic stresses are major constraints for crop yield and global food security. Among the biotic stresses, pathogens, insects and weeds cause significant losses in crop production (Rahman et al., 2018) and about 34\% loss in yield of major crops' are caused by weeds annually (Oerke, 2006). Wheat (Triticum aestivum L.) 
is the most important crop of the world and Chenopodium album is the most prevailing weed in the wheat fields (Siddiqui and Bajwa, 2001) leading to significant reduction in grain yield up to $65 \%$ (Siddiqui, 2005). Several management strategies like manual, mechanical, cultural methods and chemical herbicides are used to control C. album. The common herbicides applied for chemical control of weeds include isoproturon, 2,4dichlorophenoxyacetic acid (2,4-D), clodinafop, fenoxaprop, sulfosulfuron, tralkoxydin and tribenuron-methyl etc. (Brar and Walia, 1993). However, chemical herbicides are more hazardous in nature and cause environmental pollution. Therefore, development of safe and eco-friendly herbicides is an emergent necessity to control weeds (Yang et al., 2014). Biological weed control strategies can provide novel modes of action that will inhibit the growth of weeds that are resistant to more commonly used herbicides (Harding and Raizada, 2015).

Various allelochemicals produced by microorganisms such as indole acetic acid (IAA), $\delta$ - aminolevulinic acid (ALA) and glycoproteins have been reported to reduce the germination and development of weeds (Saxena et al., 1996; Mohan Babu et al., 2003; Mejri et al., 2010; Lou et al., 2016). Reduction in root length was most likely due to production and release of high amounts of auxins causing disruption of the hormonal balance critical to the growth and development of root tissues (Loper and Schroth, 1986). ALA is another natural photodynamic compound effective as a biodegradable herbicide (Sasikala et al., 1994) as well as having a promoting effect on the growth and photosynthesis of crops and vegetables (Sasaki et al., 1993). However, herbicidal activity of ALA on several plants was affected by the application methods. At low concentration $\left(0.01-10 \mathrm{mg} \mathrm{L}^{-1}\right)$, ALA showed growth promoting effects on yield of several crops (Hotta et al., 1997) whereas, it suppressed plant growth at higher concentrations (> 2mM). Zhang et al., (2006) reported that ALA at low concentrations of $0.3-3 \mathrm{mg} \mathrm{L}^{-1}$ promoted development and growth of potato microtubers in vitro and enhanced protective functions against oxidative stresses, but ALA at $30 \mathrm{mg} \mathrm{L}^{-1}$ and higher concentrations may induce oxidative damage. Hyun and Song (2007) reported that production of IAA and ALA by purple nonsulfur bacteria Rhodopseudomonas promoted the seed germination and growth of tomato under axenic conditions. The present study was carried out to characterize ALAproducing rhizobacterial isolates having growth retardation effects on Chenopodium album. The seed inoculation of bacterial isolate MSA39 was found to inhibit the growth of Chenopodium album and stimulated the growth of wheat under pot house conditions.

\section{Materials and Methods}

\section{Isolation of bacteria from wheat and mustard rhizosphere}

Soil samples were collected from the rhizosphere of wheat and mustard after 60 and 90 days of plant growth from field areas of Hisar, Sirsa and Fatehabad districts in Haryana. Soil samples were serially diluted up to $10^{-4}$ and diluted soil suspension $(100 \mu \mathrm{l})$ was plated on King's B and Luria Bertani (LB) medium (Sambrook et al., 1989) plates. The plates were incubated at $28 \pm 2^{\circ} \mathrm{C}$ in BOD incubator for 3-4 days. Pseudomonas, Bacillus and other rhizobacterial colonies were selected based on typical morphological and pigment production characteristics. Selected rhizobacterial isolates were maintained by periodic transfer on LB slants and were stored at $4{ }^{\circ} \mathrm{C}$ in refrigerator for further use. 
Screening of rhizobacterial isolates for ALA production

Bacterial isolates were inoculated in duplicate in $10 \mathrm{ml} \mathrm{LB}$ broth supplemented with $15 \mathrm{mM}$ glycine and succinate, and were incubated at $28 \pm 2^{\circ} \mathrm{C}$ for $48 \mathrm{hrs}$ under stationary growth conditions. Culture samples were withdrawn and centrifuged at 10,000 rpm for $15 \mathrm{~min}$ (Remi Instruments, Mumbai, India). ALA was determined in the culture supernatant by the method as described by Mauzerall and Garnick (1955). To $0.5 \mathrm{ml}$ of culture supernatant, $50 \mu \mathrm{l}$ of acetylacetone and $0.5 \mathrm{ml}$ of $1 \mathrm{M}$ sodium acetate buffer were added. Then tubes were boiled in a water bath for 15 min. After cooling, $3.5 \mathrm{ml}$ of modified Ehrlich reagent were added. The absorbance of the mixture was measured at $556 \mathrm{~nm}$ wavelength after $20 \mathrm{~min}$ at room temperature. The concentration of ALA in the culture supernatant was determined by comparison with standard curve.

\section{IAA production by rhizobacterial isolates}

Bacterial cultures were inoculated in duplicate in $30 \mathrm{ml} \mathrm{LB}$ broth supplemented with DLtryptophan@ @ $100 \mu \mathrm{g} \mathrm{ml}^{-1}$ and were incubated at $28 \pm 2^{\circ} \mathrm{C}$ for 72 hours under stationary conditions of growth. Culture samples were withdrawn after 72 hours and centrifuged at $10,000 \mathrm{rpm}$ for 15 minutes (Remi Instruments, Mumbai, India). IAA was determined in the culture supernatant as described by Gordon and Weber (1951). Two $\mathrm{ml}$ of Salkowski reagent was added to two $\mathrm{ml}$ of culture supernatant, mixed and allowed to stand for $30 \mathrm{~min}$ for the development of pink colour. Colour intensity was estimated at 500 $\mathrm{nm}$ wavelength using spectrophotometer (UV-Vis spectrophotometer 117, Systronics Ahemadabad, India) against a reagent blank. Indole acetic acid $\left(100 \mu \mathrm{g} \mathrm{ml}^{-1}\right)$ was used as standard and results were expressed as $\mu \mathrm{g}$ IAA produced $\mathrm{ml}^{-1}$ of culture supernatant.
Utilization of 1-aminocyclopropane-1carboxylate (ACC) by rhizobacterial isolates

Minimal medium (Dworkin and Foster, 1958) supplemented with $3 \mathrm{mM}$ ACC was prepared and loopful of $48 \mathrm{hrs}$ old growth of rhizobacterial isolate was spotted on medium plates. Growth of bacterial isolate was recorded after 5 days of incubation at $28 \pm 2^{0} \mathrm{C}$. The bacterial isolates showing good growth on ACC supplemented medium plates, indicating their efficiency of ACC utilization as nitrogen source, were scored as ACC utilizing isolates. Minimal medium plates containing ammonium sulfate were used as control plate for growth comparison of different bacterial isolates.

Effect of rhizobacterial isolates on seed germination and seedling growth of $C$. album

All the ALA producing rhizobacterial isolates were screened for their effect on seed germination and seedling growth of $C$. album weed on plain water agar $(0.8 \%)$ plates. Seeds were surface sterilized with sulphuric acidalcohol $(70: 30, \mathrm{v} / \mathrm{v})$ for 5 minutes followed by 5-6 successive washings with sterile distilled water (Jangu and Sindhu, 2011). These seeds were inoculated with different bacterial isolates $\left(10^{8} \mathrm{cfu} \mathrm{ml}^{-1}\right)$ for 40 minutes. Inoculated seeds were grown on $0.8 \%$ water agar plates and incubated at $28 \pm 2^{\circ} \mathrm{C}$. Seeds treated with sterilized LB broth alone were kept as control. Root and shoot length was recorded after 5 and 10 days of germination.

Inoculation effect of rhizobacteria on growth of weed and wheat

Selected rhizobacterial isolate(s) were inoculated on the seeds of the weed Chenopodium album and wheat (Triticum aestivum) variety WH711 under pot house 
conditions (Sindhu et al., 2002). Pots of $10 \mathrm{~kg}$ capacity were filled with sandy soil. Seeds of wheat and weed were inoculated with $10 \mathrm{ml}$ culture suspension of bacteria $\left(10^{7}-10^{8}\right.$ cells $\mathrm{ml}^{-1}$ of growth suspension). Inoculated seeds were sown in pots (with three replications for each treatment). Uninoculated seeds were sown as control.

Soil was supplemented with required doses of nitrogen and phosphorus fertilizers. After germination, five healthy seedlings were kept in each pot. The observations for root and shoot growth of wheat and weeds were recorded at 60 and 90 days of plant growth. Plants were carefully uprooted and washed under tap water. Roots were separated from the shoots. Shoot and root portions of the plants were dried in oven at $90^{\circ} \mathrm{C}$ for 24 hours and weighed.

\section{Results and Discussion}

\section{Isolation of rhizobacteria from wheat and mustard rhizosphere}

Ninety five bacteria were obtained from the rhizosphere of wheat and mustard. These bacteria were mainly selected on the basis of morphological characteristics resembling to Bacillus and Pseudomonas species. In earlier studies, Kennedy et al., (1991) screened 1000 isolates of pseudomonads for growth inhibition of downy brome (Bromus tectorum). Similarly, Li and Kremer (2006) demonstrated that Pseudomonas fluorescens strain G2-11 inoculated to wheat and soybean crops suppressed the growth of Ipomea sp. and Convolvolus arvensis weeds while promoting the growth of agricultural crops. Kennedy and Stubbs (2007) screened 10000 bacterial isolates obtained from wheat, jointed goatgrass (Aegilops cylindrical) and downy brome (Bromus tectorum) rhizospheres for growth inhibition of jointed goatgrass and downy brome weed.

\section{ALA production by rhizobacterial isolates}

ALA has been reported to promote the growth and yield of agricultural crops at low concentration and also used as biodegradable herbicide, when produced at high concentration by rhizobacteria. Overall, $80 \%$ of the rhizobacterial isolates were found to produce ALA.

More ALA production (> $11 \mu \mathrm{g} \mathrm{ml}^{-1}$ ) was observed in eight bacterial isolates WSA38, MSA57, WSA68, WSA56, MSA42, MSA39, WHA98 and MSA11 (Table 1; Fig. 1). Other 54 isolates produced ALA ranging from 5 to $11 \mu \mathrm{g} \mathrm{ml}^{-1}$. Twelve bacterial isolates produced ALA more than $2 \mu \mathrm{g} \mathrm{ml}{ }^{-1}$ whereas, two isolates WSA10 and WSA20 produced less than $1.0 \mu \mathrm{g} \mathrm{ml}^{-1}$ of ALA. Nineteen isolates lacked ALA production ability.

In similar studies, Hotta et al., (1997b) demonstrated that low concentration (0.01-10 $\mathrm{mg} \mathrm{L}^{-1}$ ) of ALA showed growth promoting effect on crops, whereas it suppressed plant growth at higher concentrations $(>2 \mathrm{mM})$. Liu (2005) selected seven stains of Rhodopseudomonas sp. from 36 photosynthetic bacterial stains. Rhodopseudomonas sp. strain 99-28 showed highest 5-aminolevulinic acid (ALA) production ability among these seven strains.

Rhodopseudomonas sp. 99-28 strain was mutated using ultraviolet radiation and a mutant strain L-1, which showed ALA production is higher than wild strain 99-28 was obtained. When levulinic acid (LA), glycine and succinate were supplied, ALA production was dramatically increased.

Xu et al., (2015) observed that the combined treatment of ALA and ZJ0273 synergizes the herbicide toxicity which is different from its independent effects on $M$. aquaticum and thus, could improve weed control efficacy. 
Inoculation effect of bacterial isolates on seedling growth of Chenopodium album

Rhizobacterial isolates that inhibited weeds but not agriculture crops, will have a potential to develop an effective bacteria-based weed management control method. Eight ALA producing and two ALA non-producing bacterial isolates were selected to observe their effect on growth of weed Chenopodium album on $0.8 \%$ agar incorporated plates. Out of 10 isolates, four isolates showed root growth inhibition on $5^{\text {th }}$ day of seedling growth (Table 2; Fig. 2). Five rhizobacterial isolates showed root growth inhibition on $10^{\text {th }}$ day of seed germination. Four rhizobacterial isolates MSA16, MSA39, WSA12 and WHA82 showed root growth inhibition at both $5^{\text {th }}$ and $10^{\text {th }}$ day of seedling growth. Three rhizobacterial isolates i.e., MSA16, WHA82 and WHA100 caused shoot growth inhibition on $5^{\text {th }}$ day of seed germination and three bacterial isolates MSA16, WHA82 and WHA100 caused shoot growth inhibition at $10^{\text {th }}$ day of seed germination. Three bacterial isolates MSA16, WHA82 and WHA100 caused shoot growth inhibition at both $5^{\text {th }}$ and $10^{\text {th }}$ day of seedling growth.

Loper and Schroth (1986) found that application of two bacterial strains belonging to Enterobacteriaceae reduced the plant root elongation and increased shoot/root ratio in sugarbeet. It was suggested that phytoalexins produced by seedlings as a host defense response after inoculation of rhizobacteria, could be inhibitory for seedling growth initially. In a similar study, five rhizobacterial isolates caused the germination inhibition of Sida acuta by 75, 50, 25, 50 and 50\%, respectively (Patil, 2014). Lee et al., (2008) reported that application of Rhodopseudomonas sp. KL9 enhanced growth, fruit formation, yield and the quality of fruit in tomato plants in greenhouse.
Indole acetic acid production by rhizobacterial isolates

Selected rhizobacterial isolates were tested for production of IAA at 2 days of growth. Out of 10 isolates tested, four isolates produced IAA ranging from 1 to $4 \mu \mathrm{g} \mathrm{ml}^{-1}$ (Table 3). Five isolates produced IAA ranging from 4-7 $\mu \mathrm{g}$ $\mathrm{ml}^{-1}$ and one isolate WHA82 lacked IAA production ability. In earlier studies, different bacterial strains have been found to produce IAA in varying amounts (Prikryl et al., 1985; Keyeo et al., 2011). Suzuki et al., (2003) isolated IAA low-producing spontaneous $P$. fluorescens mutant HP72LI and the colonization of strain HP72 on the root of bentgrass caused reduction in root growth, whereas strain HP72LI did not induce such growth reduction. Kim and Kremer (2005) reported IAA production in Bacillus japonicum isolate GD3, which gave suppressive effect on Morning glory growth. Out of 95 isolates, IAA production was observed in 65 isolates. Isolate VSMGT1014 produced $15.96 \mu \mathrm{g} \mathrm{ml}{ }^{-1}$ IAA in the Ltryptophan supplemented $(0.5 \%)$ ISP-2 medium. The selected strain VSMGT1014 significantly enhanced the growth of rice plants compared with that of non-inoculated plants (Harikrishnan et al., 2014). The results showed an increase in root and shoot length 52 and $54.55 \%$, respectively as compared to control.

\section{ACC utilization by rhizobacterial isolates}

Four rhizobacterial isolates MSA39, WSA12, WSA68 and WHA100 showed moderate growth on ACC supplemented medium plates (Table 3). Four isolates showed little growth and two isolates did not grow on ACC supplemented plates. Peyachoknagul et al., (1997) selected 55 bacterial isolates from 35 soil samples that were capable of growing on DF minimal medium. Among these, 6 Pseudomonas strains showed the highest 
efficiency of ACC utilization. Screening of 563 bacteria isolated from the roots of pea, lentil and chickpea, showed that $5 \%$ isolates showed ACC deaminase activity, $7 \%$ isolates were capable of indole production and $76 \%$ isolates produced siderophore (Hynes et al., 2008).

Table.1 Production of $\delta$-aminolevulinic by rhizobacterial isolates

\begin{tabular}{|c|c|}
\hline Rhizobacterial isolates & $\begin{array}{l}\text { ALA } \\
\text { production } \\
\left(\mu \mathrm{ml}^{-1}\right)\end{array}$ \\
\hline $\begin{array}{l}\text { MSA5, MSA41, MSA70, MHA108, WSA10, WSA12, } \\
\text { WSA20, WSA25, WSA42, WSA59, WSA64, WHA88, } \\
\text { WHA108, WHA123 }\end{array}$ & $<5.0$ \\
\hline $\begin{array}{l}\text { MSA1, MSA25, MSA29, MSA31, MSA35, MSA48, } \\
\text { MSA50, MSA51, MSA54, MSA56, MSA58, MSA68, } \\
\text { MHA74, MHA75, MHA79, MHA82, MHA91, MHA92, } \\
\text { MHA93, MHA107, MHA118, WSA3, WSA4, WSA1, } \\
\text { WSA16, WSA18, WSA21, WSA26, WSA28, WSA30, } \\
\text { WSA33, WSA35, WSA36, WSA43, WSA47, WSA57, } \\
\text { WSA61, WHA75, WHA80, WHA82, WHA85, WHA8,, } \\
\text { WHA96, WHA100, WHA106, WHA109 }\end{array}$ & $5.0-10.0$ \\
\hline $\begin{array}{l}\text { MSA11, MSA16, MSA21, MSA26, MSA39, MSA42, } \\
\text { MSA57, MHA104, WSA7, WSA38, WSA49, WSA50, } \\
\text { WSA56, WSA68, WHA98, WHA107 }\end{array}$ & $10.0-16.0 \mathrm{ug} / \mathrm{ml}$ \\
\hline $\begin{array}{l}\text { MSA4, MSA7, MSA12, MSA22, MSA32, MSA40, MSA63, } \\
\text { MHA71, MHA89, MHA109, MHA125, WSA44, WSA51, } \\
\text { WSA52, WSA72, WHA82, WHA92, WHA104, WHA110 }\end{array}$ & 0.0 \\
\hline
\end{tabular}

Table.2 Effect of rhizobacterial isolates on growth of Chenopodium album seedlings

\begin{tabular}{|c|c|c|c|c|c|}
\hline \multirow{3}{*}{$\begin{array}{l}\text { Rhizobacterial } \\
\text { isolates }\end{array}$} & \multirow{3}{*}{$\begin{array}{l}\text { ALA } \\
\text { production } \\
\left(\mu \mathrm{g} \mathrm{m}^{-1}\right)\end{array}$} & \multicolumn{4}{|c|}{ Observations at } \\
\hline & & \multicolumn{2}{|l|}{$5^{\text {th }}$ day } & \multicolumn{2}{|l|}{$10^{\text {th }}$ day } \\
\hline & & Root $(\mathrm{cm})$ & Shoot $(\mathrm{cm})$ & Root $(\mathrm{cm})$ & Shoot $(\mathrm{cm})$ \\
\hline Control & 0.0 & 2.0 & 6.0 & 5.0 & 9.0 \\
\hline MSA5 & 1.37 & 2.8 & 6.5 & 5.3 & 9.9 \\
\hline MSA16 & 10.83 & 1.6 & 5.0 & 3.5 & 8.9 \\
\hline MSA39 & 11.96 & 1.0 & 7.1 & 3.9 & 9.7 \\
\hline MSA40 & 0.0 & 2.3 & 7.5 & 5.5 & 11.4 \\
\hline MSA51 & 9.10 & 2.9 & 7.8 & 5.5 & 10.9 \\
\hline WSA12 & 3.94 & 1.0 & 6.5 & 3.7 & 11.9 \\
\hline WSA16 & 9.87 & 3.1 & 7.0 & 5.9 & 10.7 \\
\hline WSA68 & 11.37 & 2.5 & 6.5 & 5.8 & 10.5 \\
\hline WHA82 & 0.0 & 1.3 & 4.5 & 3.9 & 8.5 \\
\hline WHA100 & 8.75 & 2.5 & 4.0 & 4.5 & 8.5 \\
\hline
\end{tabular}


Table.3 IAA production and ACC utilization by rhizobacterial isolates

\begin{tabular}{|l|c|c|}
\hline $\begin{array}{l}\text { Rhizobacterial } \\
\text { isolates }\end{array}$ & $\begin{array}{c}\text { IAA production } \\
\left({\boldsymbol{\mu g ~} \mathbf{~}^{-1}}^{\mathbf{1}}\right)\end{array}$ & ACC utilization \\
\hline MSA5 & 4.31 & - \\
\hline MSA16 & 2.04 & + \\
\hline MSA39 & 1.0 & $2+$ \\
\hline MSA40 & 4.76 & + \\
\hline MSA51 & 6.26 & + \\
\hline WSA12 & 3.25 & $2+$ \\
\hline WSA16 & 2.95 & + \\
\hline WSA68 & 4.49 & $2+$ \\
\hline WHA82 & 0.0 & - \\
\hline WHA100 & 5.34 & $2+$ \\
\hline
\end{tabular}

Growth characteristics of rhizobacterial isolates on ACC supplemented minimal medium + , less growth, ++ , moderate growth, - , no growth

Table.4 Differential characteristics of rhizobacterial isolates selected for inoculation

\begin{tabular}{|c|c|c|c|c|c|c|c|}
\hline \multirow{3}{*}{$\begin{array}{l}\text { Rhizobacterial } \\
\text { isolates }\end{array}$} & \multirow{3}{*}{$\begin{array}{l}\text { ALA } \\
\text { production } \\
\left(\mu \mathrm{gl}^{-1}\right)\end{array}$} & \multirow{3}{*}{$\begin{array}{l}\text { IAA } \\
\text { production } \\
\left(\mu \mathrm{gl}^{-1}\right)\end{array}$} & \multirow{3}{*}{$\begin{array}{c}\text { ACC } \\
\text { utilization }\end{array}$} & \multicolumn{4}{|c|}{ Effect on growth of $C$. album } \\
\hline & & & & \multicolumn{2}{|c|}{$5^{\text {th }}$ day } & \multicolumn{2}{|c|}{$10^{\text {th }}$ day } \\
\hline & & & & $\begin{array}{l}\text { Root } \\
(\mathrm{cm})\end{array}$ & $\begin{array}{l}\text { Shoot } \\
(\mathrm{cm})\end{array}$ & $\begin{array}{l}\text { Root } \\
(\mathrm{cm})\end{array}$ & $\begin{array}{l}\text { Shoot } \\
(\mathrm{cm})\end{array}$ \\
\hline MSA39 & 11.96 & 1.0 & ++ & 1.0 & 7.1 & 3.9 & 9.7 \\
\hline WHA100 & 8.75 & 5.34 & ++ & 2.5 & 4.0 & 4.5 & 8.5 \\
\hline WHA82 & 0.0 & 0.0 & - & 1.3 & 4.5 & 3.9 & 8.5 \\
\hline
\end{tabular}

Fig.1 Production of $\delta$-aminolevulinic acid by rhizobacterial isolates

\section{ALA production}

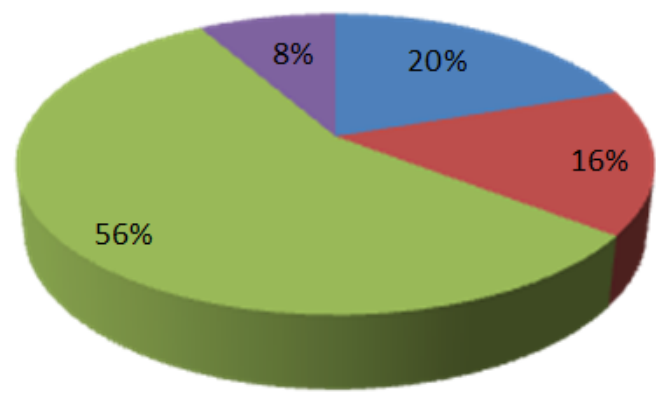

- Nil $(0 \mu \mathrm{g} / \mathrm{ml})$

- $\operatorname{Low}(<5.0 \mu \mathrm{g} / \mathrm{ml})$

Medium $(5.0-11.0 \mu \mathrm{g} / \mathrm{ml})$

= High $(>11.0 \mu \mathrm{g} / \mathrm{ml})$ 
Table.5 Effect of bacterial inoculation on plant biomass of wheat and weeds at 60 and 90 days after sowing

\begin{tabular}{|c|c|c|c|c|c|}
\hline \multirow[t]{2}{*}{ Treatment } & \multirow{2}{*}{$\begin{array}{c}\text { Plant } \\
\text { growth at } \\
\text { different } \\
\text { days }\end{array}$} & \multicolumn{2}{|c|}{$\begin{array}{l}\text { Dry weight of } \\
\text { wheat }\end{array}$} & \multicolumn{2}{|c|}{ Dry weight of weed } \\
\hline & & $\begin{array}{l}\text { Root } \\
(\mathrm{mg})\end{array}$ & $\begin{array}{l}\text { Shoot } \\
(\mathrm{mg})\end{array}$ & $\begin{array}{l}\text { Root } \\
(\mathrm{mg})\end{array}$ & $\begin{array}{l}\text { Shoot } \\
(\mathrm{mg})\end{array}$ \\
\hline \multirow{2}{*}{$\begin{array}{l}\text { T1: Control (uninoculated } \\
\text { soil) + Wheat }\end{array}$} & $*$ & 160.03 & 360.32 & - & - \\
\hline & $* *$ & 170.78 & 450.24 & - & - \\
\hline \multirow{2}{*}{$\begin{array}{l}\text { T2: Control (uninoculated soil } \\
+ \text { N, P fertilizers) + Wheat }\end{array}$} & $*$ & 180.32 & 210.11 & - & - \\
\hline & $* *$ & 198.57 & 478.65 & - & - \\
\hline \multirow[t]{2}{*}{ T1 + Weed (C. album) } & $*$ & - & - & 390.13 & 800.23 \\
\hline & $* *$ & - & - & 490.50 & 950.34 \\
\hline \multirow[t]{2}{*}{ T2 + Weed (C. album) } & $*$ & - & - & 480.09 & 970.87 \\
\hline & $* *$ & - & - & 550.02 & 1151.89 \\
\hline \multirow[t]{2}{*}{ T1 + Wheat + Weed } & $*$ & 269.65 & 320.08 & 110.78 & 430.00 \\
\hline & $* *$ & 250.89 & 487.56 & 170.56 & 506.02 \\
\hline \multirow[t]{2}{*}{ T2 + Wheat + Weed } & $*$ & 245.67 & 396.87 & 160.86 & 480.65 \\
\hline & $* *$ & 342.50 & 477.89 & 290.45 & 538.00 \\
\hline \multirow[t]{2}{*}{ T2 + Wheat + WHA82 } & $*$ & 190.67 & 250.45 & - & - \\
\hline & $* *$ & 261.42 & 435.70 & - & - \\
\hline \multirow[t]{2}{*}{ T2 + Weed + WHA82 } & $*$ & - & - & 490.34 & 700.32 \\
\hline & $* *$ & - & - & 570.45 & 926.00 \\
\hline \multirow{2}{*}{$\begin{array}{l}\text { T2 + Wheat }+ \text { Weed }+ \\
\text { WHA82 }\end{array}$} & $*$ & 220.32 & 360.80 & 250.55 & 320.22 \\
\hline & $* *$ & 390.00 & 596.00 & 318.00 & 492.00 \\
\hline \multirow[t]{2}{*}{ T2 + Wheat + WHA100 } & $*$ & 290.87 & 380.12 & - & - \\
\hline & $* *$ & 332.85 & 517.45 & - & - \\
\hline \multirow[t]{2}{*}{ T2 + Weed + WHA100 } & $*$ & - & - & 216.54 & 512.88 \\
\hline & $* *$ & - & - & 343.67 & 564.00 \\
\hline \multirow{2}{*}{$\begin{array}{l}\text { T2 + Wheat }+ \text { Weed }+ \\
\text { WHA100 }\end{array}$} & $*$ & 370.56 & 580.34 & 160.45 & 248.33 \\
\hline & $* *$ & 500.50 & 670.00 & 245.50 & 338.89 \\
\hline \multirow[t]{2}{*}{ T2 + Wheat + MSA39 } & $*$ & 220.5 & 430.80 & - & - \\
\hline & $* *$ & 287.5 & 595.78 & - & - \\
\hline \multirow[t]{2}{*}{ T2 + Weed + MSA39 } & $*$ & - & - & 210.8 & 308.50 \\
\hline & $* *$ & - & - & 292.78 & 550.89 \\
\hline \multirow[t]{2}{*}{ T2 + Wheat + Weed + MSA39 } & $*$ & 136.66 & 360.67 & 265.03 & 345.04 \\
\hline & $* *$ & 295.00 & 475.56 & 287.08 & 387.56 \\
\hline \multirow[t]{2}{*}{ CD } & $*$ & 2.676 & 5.776 & 2.785 & 2.702 \\
\hline & $* *$ & 2.728 & 2.771 & 2.864 & 2.663 \\
\hline
\end{tabular}


Fig.2 Effect of bacterial isolate MSA39 on growth of $C$. album seedlings at 5 days of growth

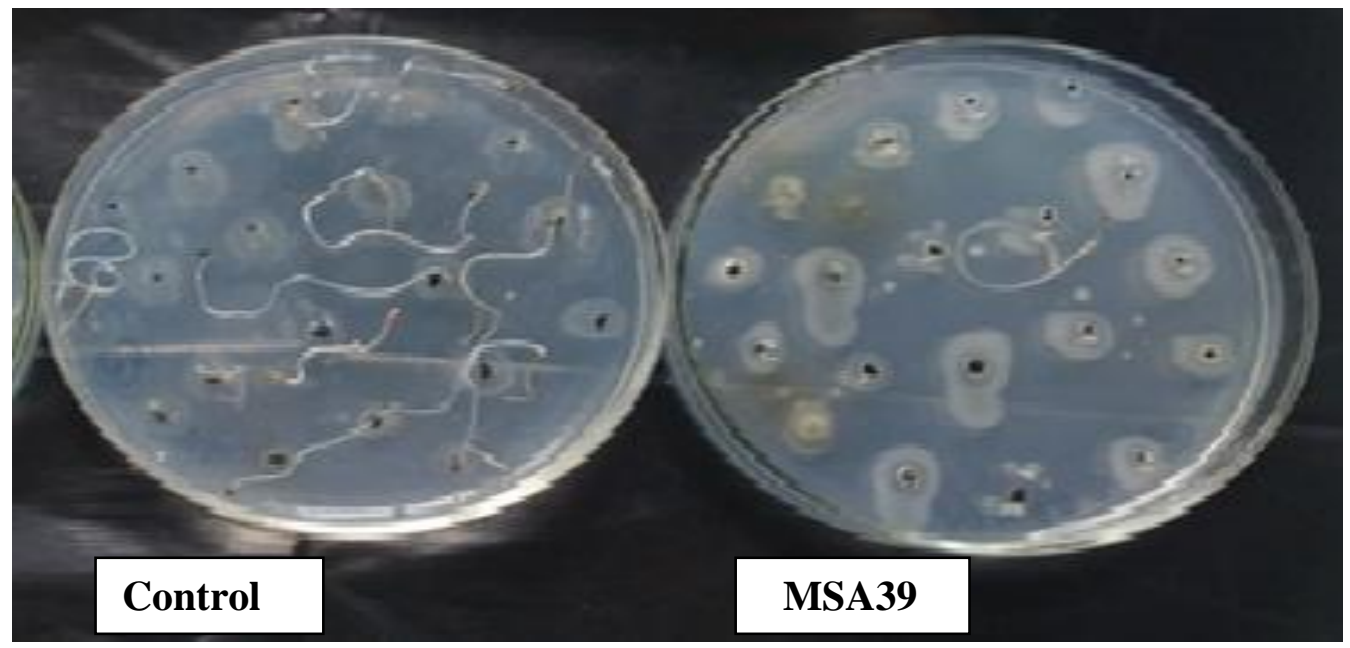

Fig.3 Effect of bacterial inoculation on plant biomass of wheat and Chenopodium album at 60 days after sowing

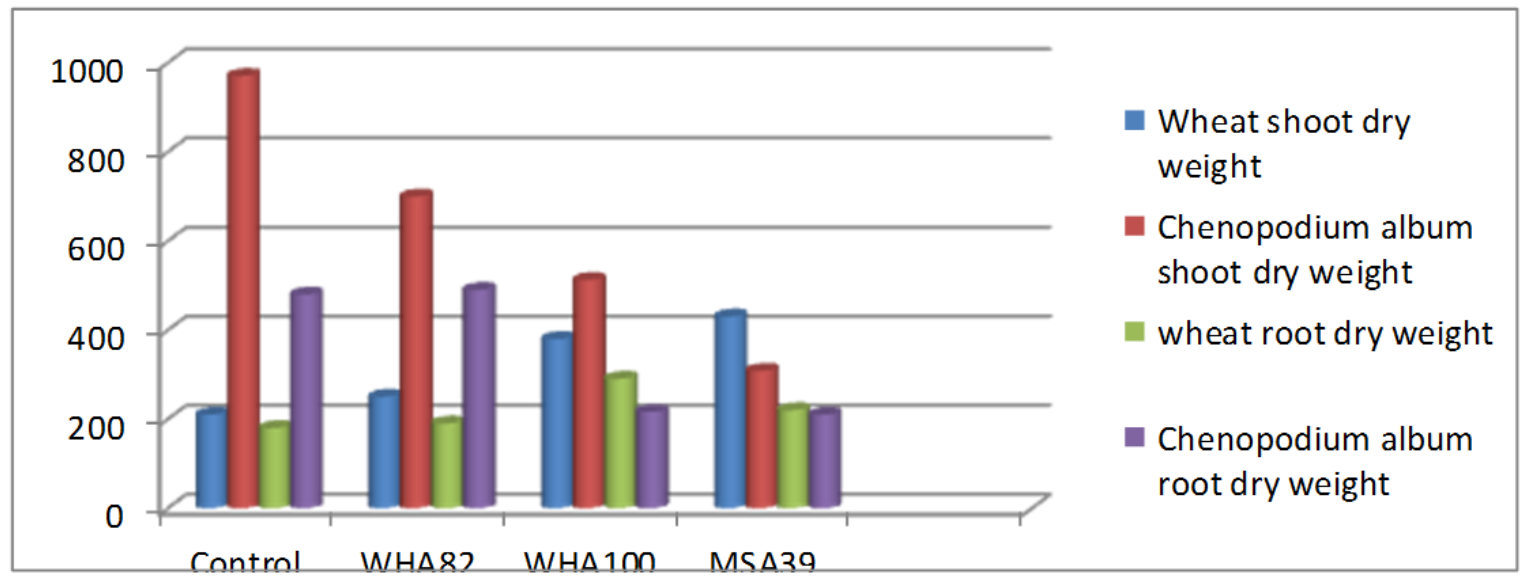

Fig.4 Effect of bacterial inoculation on plant biomass of wheat and Chenopodium album at 90 days after sowing

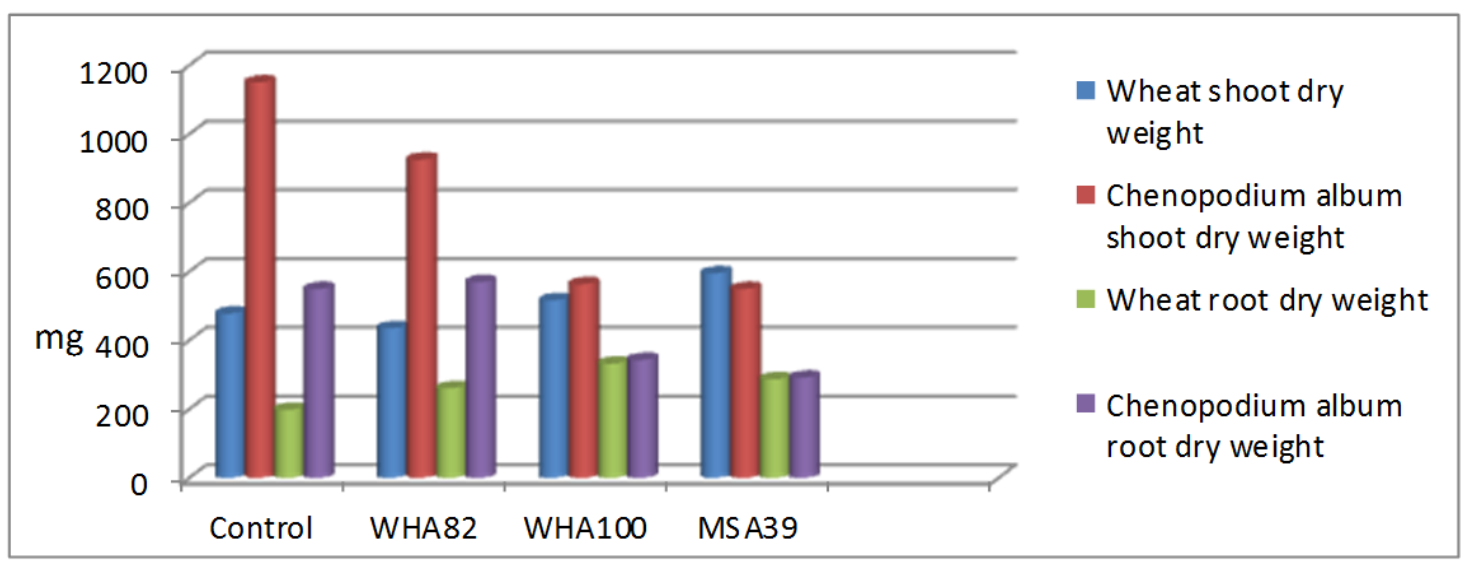


Fig.5 Effect of inoculation with bacterial isolates on the growth of wheat and weed (C. album) plants with different treatments at 60 days after sowing

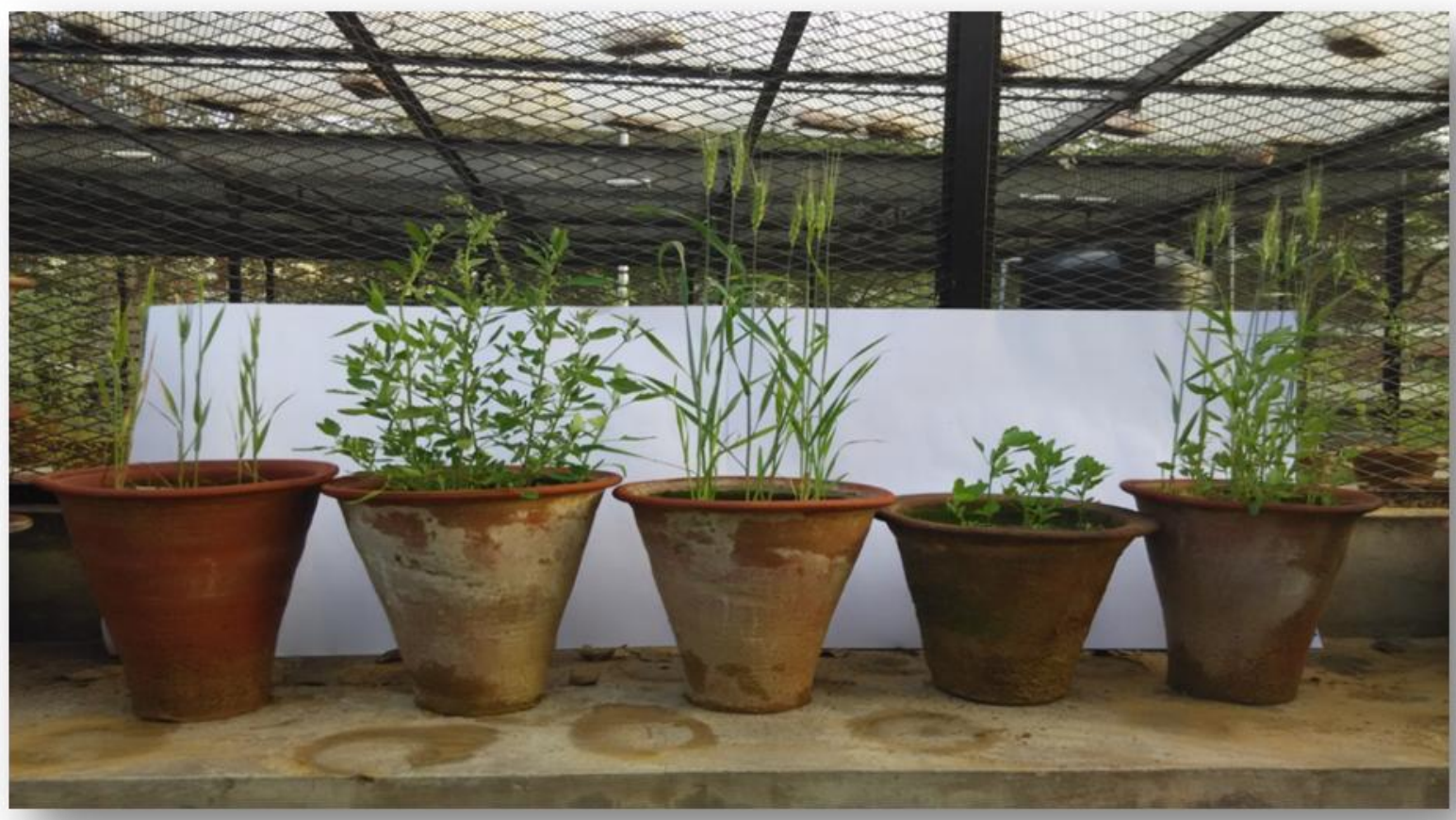

A: Control (uninoculated soil + N, P fertilizers) + Wheat; B: $\mathrm{T}_{2}+$ Weed (C. album); C: $\mathrm{T}_{2}+$ Wheat + WSA39; D: $\mathrm{T}_{2}$ + Weed + WSA39; E: T $_{2}+$ Wheat + Weed + WSA39

Zafar-ul-Hye et al., (2014) explored the effect of PGPR containing ACC deaminase alone and in combination with mineral fertilizers on yield and nutrient uptake of maize under drought in saline field. Inoculation of two PGPR strains S1 (Pseudomonas syringae) and $\mathrm{S} 2$ ( $P$. fluorescens) to the maize seeds in separate and along with full and half dose of recommended NPK fertilizers caused 55.14\% increase in plant biomass and yield.

\section{Inoculation effect of rhizosphere bacteria on growth of wheat and weed}

Three bacterial isolates i.e., WHA82, MSA39 and WHA100 were selected, on the basis of different beneficial properties (Table 4) to study their effect on growth of wheat and weed under pot house conditions. At 60 days of observation, inoculation of bacterial isolate MSA39 showed 43\% decrease in RDW and
$31 \%$ decrease in SDW of C. album, whereas its inoculation caused $122 \%$ increase in RDW and $205.6 \%$ increase in SDW of wheat (Table 5; Fig. 3). Inoculation with bacterial isolate WHA100 caused $45 \%$ decrease in RDW and $52 \%$ decrease in SDW of C. album and resulted in 161 and $180 \%$ gain in RDW and SDW of wheat, respectively. On the other hand, inoculation with bacterial isolate WHA82 increased the root dry weight but decreased the shoot dry weight of C. album. At 90 days of observation, inoculation of bacterial isolate MSA39 caused 53\% decrease in RDW and $47.7 \%$ decrease in SDW of Chenopodium album, whereas its inoculation caused $144 \%$ increase in RDW and 124\% increase in SDW of wheat (Table 5; Fig. 4 and 5). Inoculation with bacterial isolate WHA100 caused $62 \%$ decrease in RDW and $49 \%$ decrease in SDW of C. album and its inoculation caused 167 and 108\% increase in 
root dry weight and shoot dry weight of wheat, respectively. Similarly, inoculation with bacterial isolate WHA82 showed $47 \%$ decrease in root dry weight and $80 \%$ decrease in shoot dry weight of C. album and its inoculation caused $131 \%$ increase in root dry weight and $91 \%$ decrease in shoot dry weight of wheat.

In similar studies, Shukorjuraimi et al., (2005) showed that Exserohilum longirostratum reduced growth and dry weight of barnyard grass ecotypes PK-04, L-01 and B-04, and the range of dry weight reduction was 37.58 to 86.34\%. Zermane et al., (2007) reported that $P$. fluorescens has potential for controlling Orobanche crenata and $O$. foetida (Broomrape) in Northan Tunisia. Siddiqui et al., (2010) conducted field experiment to evaluate the mycoherbicidal potential of Alternaria alternata to control Chenopodium album L. Two wheat cultivars viz. Inqalab 91 and Punjab 96 were co-cultivated with $C$. album in 1:1 crop-weed ratio.

Application of mycoherbicide significantly reduced the biomass of the target weed species up to 90\%. Akbar and Javaid (2012) tested the fungal filtrate of four Drechslera sp. on two species of weeds i.e. Chenopodium album L. (dicot) and Avena fatua L. of the wheat crop using Petri plate method and fungus filtrate affected the germination of $C$. album by $28-50 \%$, shoot length was reduced by 54 to $91 \%$ and shoot biomass decreased by 58 to $81 \%$. For A. fatua, germination decreased by $28-54 \%$ because of different filtrate concentrations. The fungal filtrate reduced the shoot length of $A$. fatua by 27 to $67 \%$ and shoot biomass was reduced by 27 to $57 \%$.

The inoculation of the filtrate obtained from the isolate LX-65 caused highest reduction in Eruca sativa, in which all dilutions of LX-65 metabolite, significantly reduced Eruca sativa germination by 47, 100, 100 and $100 \%$, shoot length by $41,100,100$ and $100 \%$, respectively, and reduced root length significantly by $65,100,100$ and $100 \%$, respectively as compared with its control (Sayed et al., 2014).

In conclusion, Mechanical and chemical methods reported previously for weed control cause increase in cost, with harmful effects on environment and low efficacy. Biocontrol methods of weed control have not been well explored, for diverse type of weeds plants. The increasing rate of appearance of herbicide-resistant weeds together with growing public concern about herbicide use will continue to be the driving force for investment and investigation of biocontrol agents (Harding and Raizada, 2015). Moreover, the use of biological control will reduce the use of synthetic agrochemicals (Hershenhorn et al., 2016).

The results obtained in this study showed that rhizospheric bacteria have a great potential to interfere with the growth of weed seedlings. Inoculation of bacterial isolate MSA39 caused 43-53\% decrease in root dry weight and 31$47 \%$ decrease in shoot dry weight of Chenopodium album at 60 and 90 days of plant growth, whereas its inoculation showed $122-144 \%$ increase in root dry weight and 124- $205 \%$ increase in shoot dry weight of wheat. Therefore, further studies are required for developing these rhizobacteria as a potential biological agent for weed control in order to achieve agricultural sustainability, environmental safety, food security, resource conservation and economic stability.

\section{Acknowledgement}

Authors thank the Department of Microbiology, CCS Haryana Agricultural University, Hisar, India for providing necessary facilities for this work. 


\section{References}

Akbar, M., and Javaid, A. 2012. Herbicidal activity of fungal culture filtrates against Chenopodium album L. and Avena fatua L. J. Anim. Plant Sci. 22: 977-982.

Brar, L.S., and Walia, U.S. 1993. The bioefficiency of sulphonylurea against Phalaris minor in wheat. Indian $J$. Weed Sci. 25: 1-5.

Dworkin, M., and Foster, J.W. 1958. Experiments with some microorganisms which utilize ethane and hydrogen. $J$. Bacteriol. 75: 592-601.

Gordon, S.A., and Weber, R.P. 1951. Colorimetric estimation of indole acetic acid. Plant Physiol. 26: 192-195.

Harding, D. P., and Raizada, M. N. 2015. Controlling weeds with fungi, bacteria and viruses: A review. Front. Plant Sci. 6: 509 .

Harikrishnan, H. Shanmugaiah, V., and Balasubramanian, $\quad$ N. 2014. Optimization for production of IAA by plant growth promoting Streptomyces sp VSMGT1014 isolates from rice rhizosphere. Internl. J. Current Microbiol. Appl. Sci. 3: 158-171.

Hershenhorn, J., Casella, F., and Vurro, Maurizio. 2016. Weed biocontrol with fungi: past, present and future. Biocontr. Sci. Technol. 26: 1313-1328.

Hotta, Y., Tanaka, T., Takaoka, H., Takeuchi, Y., and Konnai, M. 1997. Promotive effects of 5-aminolevulinic acid on the yield of several crops. Plant Growth Regul. 22: 109-114.

Hynes, R.K., Leung, G.C., Hirkala, D.L., and Nelson, L.M. 2008. Isolation, selection, and characterization of beneficial rhizobacteria from pea, lentil and chickpea grown in western Canada. Can. J. Microbiol. 54: 248-258.

Hyun, K.R., and Song, H.G. 2007. Effects of application of Rhodopseudomonas sp. on seed germination and growth of tomato under axenic conditions. $J$. Microbiol. Biotechnol. 17: 1805-1810.

Jangu, O.P., and Sindhu, S.S. 2011. Differential response of inoculation with indole acetic acid producing Pseudomonas sp. in green gram (Vigna radiata L.) and black gram (Vigna mungo L.). Microbiol. J. 1: 159-173.

Kennedy, A., and Stubbs, T. 2007. Management effects on the incidence of jointed goatgrass inhibitory rhizobacteria. Biol. Contr. Theor. Applic.Pest Manage. 40(2): 213-221.

Kennedy, A.C., Elliott, L.F., Young, F.L., and Douglas, C.L.(1991. Rhizobacteria suppressive to the weed downy brome. Soil Sci. Soc. Am. J. 55: 722-727.

Keyeo, F., Ai'shah, O.N., and Amir, H.G. 2011. The effects of nitrogen fixation activity and phytohormone production of diazotroph in promoting growth of rice seedlings. Biotechnology 10: 267273.

Kim, S.J., and Kremer, R.J. 2005. Scanning and transmission electron microscopy of root colonization of morning glory (Ipomoea spp.) seedlings by rhizobacteria. Symbiosis 39:117-124.

Lee, K.H., Koh, R.H., and Song, H.G. 2008. Enhancement of growth and yield of tomato by Rhodopseudomonas sp. under greenhouse conditions. $J$. Microbiol. 46: 641-646.

Li, J., and Kremer, R.J. 2006. Growth response of weed and crop seedlings to deleterious rhizobacteria. Biol. Contr. 39: 58-65.

Liu, X.Y., Xu, X.Y., Ma, Q.L., and Wu, W.H. 2005. Biological formation of 5aminolevulinic acid by photosynthetic bacteria. J. Environ. Sci. 17: 152-155.

Loper, J.E., and Schroth, M.N. 1986. Influence of bacterial sources of indole3 -acetic acid on root elongation of 
sugarbeet. Phytopathology 76: 386-389.

Lou, Y., Davis, A.S., and Yannarell, A.C. 2016. Interactions between allelochemicals and the microbial community affect weed suppression following cover crop residue incorporation into soil. Plant Soil 399: 357-371.

Mauzerall, D., and Granick, S. 1955. The occurrence and determination of $\delta$ aminolevulinic acid and porphobilinogen in urine. J. Biol. Chem. 219: 435-446.

Mejri, D., Gamalero, E., Tombolini, R., Musso, C., Massa, N., Berta, G., and Souissi, T. 2010. Biological control of great brome (Bromus diandrus) in durum wheat (Triticum durum): specificity, physiological traits and impact on plant growth and root architecture of the fluorescent pseudomonad strain X33d. Biocontrol 55: 561-572.

Mohan Babu, R., Sajeena, A., Vidhyasekaran, P., Seetharaman, K., and Reddy, M.S. 2003. Characterization of a phytotoxic glycoprotein produced by Phoma eupyrena - a pathogen on water lettuce. Phytoparasitica 31: 265-274.

Oerke, E.C. 2006. Crop losses to pests. J. Agric. Sci. 144: 31-43.

Patil, V.S. 2014. Isolation, characterization and identification of rhizospheric bacteria with the potential for biological control of Sida acuta. J. Environ. Res. Develop. 8: 411-417.

Peyachoknagul, S., Pongtongkam, P., and Apisitwanich, S. 1997. Cloning of $1-$ aminocyclopropane-1-carboxylate deaminase gene from soil microorganisms. Thammasat Internl. J. Sci. Technol. 2: 56-60.

Prikryl, Z., Vancura, V., and Wurst, M. 1985. Auxin formation by rhizosphere bacteria as a factor of root growth. Biol. Plant. 27: 159-163.
Rahman, S.F.S. Ab, Singh, E., Pieterse, C.M.J., and Scenk, P.M. 2018. Emerging biocontrol strategies for plant pathogens. Plant Sci. 267: 102-111.

Sambrook, J., Fritsch, E.F., and Maniatis, T. 1989. Molecular cloning. Cold Spring Harbor Laboratory Press, Cold Spring Harbor, New York.

Sasaki, K., Tanaka, T., Nishio, N., and Nagai, S. 1993. Effect of culture $\mathrm{pH}$ on the extracellular production of 5aminolevulinic acid by Rhodobacter sphaeroides from volatile fatty acid. Biotechnol. Lett. 15: 859-864.

Sasikala, Ch., Ramana, Ch.V., and Rao, P.R. 1994. 5-aminolevulinic acid: A potential herbicide/insecticide from microorganisms. Biotechnol. Prog. 10: 451-459.

Saxena, A., Singh, D.V., and Joshi N.L. 1996. Allelopathy in agroecosystems. Field Crop Abst. 49: 891-899.

Sayed, M.H.E., Aziz, Z.K.A., and Abouzaid, A.M. 2014. Efficacy of extracellular metabolite produced by Streptomyces levis Strain LX-65 as a potential herbicidal agent. J. American Sci. 10: 169-180.

Shukorjuraimi, A., Tasrif, A., Kadir, J., Napis, J., and Sastroutomo, S.S. 2005. Phytotoxicity and field efficacy of Exserohilum longirostra for the control of barnyard grass. Biotropia 24: 20-29.

Siddiqui, I. 2005. Fungal pathogens as biological control agents of weeds of wheat. Ph. D. thesis. University of the Punjab, Quaid-e- Azam campus, Lahore, Pakistan.

Siddiqui, I., and Bajwa, R. 2001. Variation in weed composition in wheat fields of Lahore and Gujranwala divisions. Pakistan J. Biol. Sci. 4: 492-504.

Siddiqui, I., Bajwa, R., and Javaid, A. 2010. Mycoherbicidal potential of Alternaria alternata for management of Chenopodium album under field 
condition. African J. Biotechnol. 9: 8308-8312.

Sindhu, S.S., Sunita Suneja, Goel, A.K., Parmar, N., and Dadarwal, K.R. 2002. Plant growth promoting effects of Pseudomonas sp. on coinoculation with Mesorhizobium sp. Cicer strain under sterile and wilt sick soil conditions. Appl. Soil Ecol. 19: 57-64.

Suzuki, S., Yuxi, H., and Oyaizu, H. 2003. Indole-3-acetic acid production in Pseudomonas fluorescens HP72 and its association with suppression of creeping bentgrass brown patch. Curr. Microbiol. 47(2): 138-143.

Xu, L., Zhang, W., Ali, B., Islam, F., Zhu, J., and Zhou, W. 2015. Synergism of herbicide toxicity by 5 -aminolevulinic acid is related to physiological and ultra-structural disorders in crickweed (Malachium aquaticum L.). Pestic. Biochem. Physiol. 125: 53-61.

Yang, J., Cao, H., Wang, W., Zhang, L., and Dong, J. 2014. Isolation, identification, and herbicidal activity of metabolites produced by Pseudomonas aeruginosa CB-4. J. Integr. Agric. 13:1719-1726.
Zafar-ul-Hye, M., Farooq, H.M., Zahir, Z.A., Hussain, M., and Hussain, A. 2014. Application of ACCdeaminase containing rhizobacteria with fertilizer improves maize production under drought and salinity stress. Internl $J$ Agric Biol. 16: 591-596.

Zermane, N., Souissi, T., Kroschel, J., and Sikora, R. 2007. Biocontrol of broom rape (Orobanche crenata Forsk. and Orobanche foetida Poir.) by Pseudomonas fluorescens isolate Bf7-9 from the faba bean rhizosphere. Biocontr. Sci. Technol. 17: 487-497.

Zhang, Z.J., Li, H.Z, Zhou, W.J., Takeuchi, Y., and Yoneyama, K. 2006. Effect of 5-aminolevulinic acid on development and salt tolerance of potato (Solanum tuberosum L.) microtubers in vitro. Plant Growth Regul. 49: 27-34.

Zhen, A., Bie, Z.L., Huang, Y., Liu, Z.X., and Fan, M.L. 2012. Effects of 5aminolevulinic acid on the $\mathrm{H} 2 \mathrm{O} 2$ content and antioxidative enzyme gene expression in $\mathrm{NaCl}$ treated cucumber seedlings. Biol. Plant. 56: 566-570.

\section{How to cite this article:}

Aakanksha Khandelwal, Anju Sehrawat and Satyavir S. Sindhu. 2018. Techniques for Determination of Vitamin $\mathrm{B}_{6}$, Vitamin C and Variability in Areca Nut (Areca catechu) Samples of Karnataka, India. Int.J.Curr.Microbiol.App.Sci. 7(02): 1958-1971. doi: https://doi.org/10.20546/ijcmas.2018.702.235 